\section{Nitrogen Fertilization Strategies for the 'Hass' Avocado that Increase Total Yield Without Reducing Fruit Size}

\author{
Jaime E. Salvo ${ }^{1}$ and Carol J. Lovatt ${ }^{2}$
}

AdDitional Index words. Persea americana, commercially valuable size fruit, fruit quality, potential nitrate pollution of groundwater, tree nitrogen demand, tree nitrogen status

SumMARY. Effects of nitrogen (N) fertilizer application times and rates on 'Hass' avocado (Persea americana) yield and fruit size were determined to resolve whether a single dose of soil-applied $\mathrm{N}[1 \times \mathrm{N}(25 \mathrm{lb} / \mathrm{acre})]$ at each of the five key stages of tree phenology (January, April, July, August, and November) (control) was as efficacious as soil-applied $2 \times \mathrm{N}(50 \mathrm{lb} / \mathrm{acre})$ at one or two key stages or soil- or foliar-applied 3x N (75 lb/acre) at only one stage. All trees received soil-applied N at $125 \mathrm{lb} /$ acre as ammonium nitrate $\left(\mathrm{NH}_{4} \mathrm{NO}_{3}\right)$ annually; trees receiving $2 \times$ or $3 \times \mathrm{N}$ received the remaining $\mathrm{N}$ divided evenly at the same phenological stages (months) as trees receiving five $1 \times \mathrm{N}$ applications. The importance of supplying $\mathrm{N}$ during the summer, when June drop, exponential fruit growth, vegetative shoot growth, and floral initiation occur, was determined by testing soil-applied $0.8 \times \mathrm{N}$ in July plus August only (40 lb/acre $\mathrm{N}$ as $\mathrm{NH}_{4} \mathrm{NO}_{3}$ annually). Application time proved an important determinant of total yield. Yield of commercially valuable size (CVS) fruit was correlated with total yield $(r=0.80, P<0.0001)$. Four-year cumulative total yields were equal for trees receiving soil-applied $1 \times \mathrm{N}$ at five key phenological stages and trees receiving soil-applied $2 x \mathrm{~N}$ in April and $18.75 \mathrm{lb} /$ acre $\mathrm{N}$ at the four other stages (months). However, trees receiving soil-applied 2x $\mathrm{N}$ in April plus November and only $8.3 \mathrm{lb} /$ acre $\mathrm{N}$ in the three other months, in particular July and August, had significantly lower 4 -year cumulative total yields $(P=0.0362)$. Additional evidence of the importance of meeting avocado tree $\mathrm{N}$ demand in the summer is that trees receiving only $40 \mathrm{lb} /$ acre $\mathrm{N}$ split in July plus August produced 4-year cumulative total yields equal to trees receiving $25 \mathrm{lb} /$ acre $\mathrm{N}$ at the five key phenological stages; lower annual $\mathrm{N}$ would reduce fertilizer expense and protect the environment.

A renewed interest in protecting the environment combined with the increasing cost of $\mathrm{N}$ fertilizer has resulted in the need for 'Hass' avocado growers worldwide to improve their $\mathrm{N}$ fertilization practices to increase yield per hectare, including yield of CVS fruit, to increase net income and sustain this commoditybased industry (Atucha et al., 2013; Lovatt, 2013; Morales-Payan and Candelas, 2013; Sukamto et al., 2014). Despite problems of low yield,

Department of Botany and Plant Sciences-072, University of California, Riverside, CA 92521-0124

This work was supported in part by the Citrus Research Center and Agricultural Experiment Station of the University of California-Riverside, National Institute of Food and Agriculture, California Avocado Commission, CA, Department of Food and Agriculture Fertilizer Research and Education Program, and Instituto de Investigaciones Agropecuarias de Chile.

We thank John Grether, Grether Farming, for the use of the orchard and assistance with the harvests.

${ }^{1}$ Current address: Instituto de Investigaciones Agropecuarias INIA La Cruz, Chorrilos 86, La Cruz, Valparaíso, 2280000, Chile

${ }^{2}$ Corresponding author. E-mail: carol.lovatt@ucr.edu. small fruit size, and alternate bearing, 'Hass' avocado dominates the global avocado industry (Garner et al., 2011). Management of $\mathrm{N}$ is complex because both avocado tree nutritional status and orchard soil fertility vary greatly among local avocado-growing areas (Batjes, 2014; Sotelo-Nava et al., $2013 a, 2013 b)$. It is further complicated by the fact that in California multiple $\mathrm{N}$ fertilizer experiments have repeatedly demonstrated that 'Hass' avocado yield and fruit size are not related to leaf $\mathrm{N}$ concentration (Arpaia et al., 1996; Embleton and Jones, 1972; Embleton et al., 1968; Lovatt, 2001; Lovatt and Witney, 2001; Yates et al., 1993). One possibility is that $\mathrm{N}$ applications in spring or summer negatively impact avocado yield by stimulating competition between developing vegetative and floral shoots or between exponentially growing fruit and vegetative shoot growth, respectively (Adato, 1990; Huett, 1996; Kalmar and Lahav, 1976; Lovatt, 2001; Whiley et al., 1996; Zilkah et al., 1987). To avoid competition, it was recommended that growers apply their total annual soil $\mathrm{N}$ in one application between January and March or two applications in January to March and June or July (Bekey, 1989). When N was supplied through the irrigation, it was suggested that the total annual $\mathrm{N}$ be applied in small amounts at the beginning of each month or every other month from March through October (Bekey, 1989). In contrast, the principle guiding the development of fertilizer best management practices to maximize yield and protect the environment is to properly time the application and amount of soilapplied fertilizer to meet the nutrient demand of the crop. This practice increases nutrient-uptake efficiency and reduces the potential for nutrient runoff and leaching (Alva et al., 2006).

In light of the proposed periods of competition for nutrients between vegetative and reproductive development in avocado tree phenology, it would seem logical to supply sufficiently high amounts of $\mathrm{N}$ to meet the demands of the competing growth processes so that floral shoot development,

\begin{tabular}{llll}
\hline $\begin{array}{l}\text { Units } \\
\text { To convert U.S. to SI, } \\
\text { multiply by }\end{array}$ & U.S. unit & SI unit & $\begin{array}{l}\text { To convert SI to U.S., } \\
\text { multiply by }\end{array}$ \\
\hline 1 & $\%$ & $\mathrm{~g} / \mathrm{l} 00 \mathrm{~g}$ & $\mathrm{l}$ \\
0.3048 & $\mathrm{ft}$ & $\mathrm{m}$ & 3.2808 \\
9.3540 & gal/acre & $\mathrm{L} \cdot \mathrm{ha}^{-1}$ & 0.1069 \\
2.54 & inch $(\mathrm{es})$ & $\mathrm{cm}$ & 0.3937 \\
25.4 & inch(es) & $\mathrm{mm}$ & 0.0394 \\
6.4516 & inch & $\mathrm{cm}^{2}$ & 0.1550 \\
0.4536 & $\mathrm{lb}$ & $\mathrm{kg}$ & 2.2046 \\
1.1209 & $\mathrm{lb} / \mathrm{acre}$ & $\mathrm{kg} \cdot \mathrm{ha}^{-1}$ & 0.8922 \\
28.3495 & $\mathrm{oz}$ & $\mathrm{g}$ & 0.0353 \\
1 & $\mathrm{ppm}$ & $\mathrm{mg} \cdot \mathrm{L}^{-1}$ & 1 \\
1 & $\mathrm{ppm}$ & $\mu \mathrm{g} \cdot \mathrm{g}^{-1}$ & 1 \\
6.8948 & $\mathrm{psi}$ & $\mathrm{kPa}$ & 0.1450 \\
$\left({ }^{\circ} \mathrm{F}-32\right) / 1.8$ & ${ }^{\circ} \mathrm{F}$ & ${ }^{\circ} \mathrm{C}$ & $\left({ }^{\circ} \mathrm{C} \times 1.8\right)+32$
\end{tabular}


fruit set, fruit growth, and vegetative shoot growth would not be compromised. Indeed, supplying a double dose of soil-applied $\mathrm{N}\left[56 \mathrm{~kg} \cdot \mathrm{ha}^{-1}\right.$ $(50.0 \mathrm{lb} /$ acre $)]$ to 'Hass' avocado trees in April or November significantly increased 4-year cumulative yield (kilograms fruit per tree) 30\% and $39 \%$, respectively, with more than $70 \%$ of the net increase in yield CVS fruit (178-325 g/fruit), compared with control trees receiving five applications of $\mathrm{N}$ at $28 \mathrm{~kg} \cdot \mathrm{ha}^{-1}$ $(25.0 \mathrm{lb} / \mathrm{acre})$ every other month from April through October $(P \leq$ $0.01)$ (Lovatt, 2001). In addition, the double dose of $\mathrm{N}$ in April significantly reduced the severity of alternate bearing.

Supplying double doses of $\mathrm{N}$ to the soil raised the concern that the amount of $\mathrm{N}$ leaching past the root zone might be increased. The results of a study evaluating nutrient and irrigation management practices in an avocado orchard in Florida documented that doubling $\mathrm{N}$ fertilization rates increased the amount of $\mathrm{N}$ in the leachate (Kiggundu et al., 2012). Similarly, $\mathrm{N}$ fertilization rates were linearly correlated with $\mathrm{N}$ concentrations in the soil water and storm water runoff for California avocado orchards in Ventura County (Mangiafico et al., 2009). A potential solution would be to replace part of the soil-applied $\mathrm{N}$ with foliar-applied $\mathrm{N}$, but the ability of avocado leaves to take up $\mathrm{N}$, especially as urea, varies among avocado-growing countries (Nevin et al., 1990; Zilkah et al., 1987). However, other organs can be targeted. A single foliar application of low-biuret urea $\left[28 \mathrm{~kg} \cdot \mathrm{ha}^{-1}(46 \% \mathrm{~N}\right.$, $\leq 0.25 \%$ biuret)] at the cauliflower stage of inflorescence development (March in California) increased 3-year cumulative net yield by $55 \mathrm{~kg}$ /tree compared with trees receiving soilapplied N (Jaganath and Lovatt, 1995)

Due to the possibility that double doses of soil-applied $\mathrm{N}$ might increase the potential for nitrate pollution of groundwater, the objective of the research reported herein was to determine whether it was necessary to supply double or triple doses of $\mathrm{N}$ to the soil at key stages of 'Hass' avocado tree phenology or whether single doses of $\mathrm{N}$ would be sufficient if each dose was supplied at a key stage in the phenology of the tree and not simply every other month. The efficacy of supplying additional $\mathrm{N}$ through the foliage at key stages tree phenology was also investigated. In this experiment, all trees received the same amount of annual total N (125 $\mathrm{lb} / \mathrm{acre}$ ), so trees receiving double or triple doses of $\mathrm{N}$ received their remaining $\mathrm{N}$ divided equally at the same phenological stages (months) the control trees were fertilized. This is in contrast to the prior research of Lovatt (2001), in which trees receiving a double dose of $\mathrm{N}$ received 28 $\mathrm{kg} \cdot \mathrm{ha}^{-1}$ more $\mathrm{N}$ than the control trees, which received $140 \mathrm{~kg} \cdot \mathrm{ha}^{-1}$ (125.0 $\mathrm{lb} / \mathrm{acre}$ ) annual N. In addition, in the research reported herein, a treatment was included to test the importance of meeting tree $\mathrm{N}$ demand during the summer, when June drop, exponential fruit growth, vegetative shoot growth, and transition from vegetative to floral development for next spring's bloom, occur concurrently (Garner and Lovatt, 2008; Lovatt, 2011; Salazar-García et al.,
1998). The treatment provided 40 $\mathrm{lb} /$ acre $\left(44.8 \mathrm{~kg} \cdot \mathrm{ha}^{-1}\right)$ annual total $\mathrm{N}$ to the soil only in July plus August, the major period of $\mathrm{N}$ uptake by 'Hass' avocado fruit (Rosecrance et al., 2012). As part of the current research, the effect of fertilization strategy on the amount of $\mathrm{N}$ leaching past the root zone as nitrate- $\mathrm{N}\left(\mathrm{NO}_{3}^{-}-\mathrm{N}\right)$ and ammonium-N $\left(\mathrm{NH}_{4}{ }^{+}-\mathrm{N}\right)$ was determined. The goal of the research was to develop a best management practice for $\mathrm{N}$ fertilization (N-BMP) of 'Hass' avocado that maximized production, including the yield of CVS fruit $(178-325 \mathrm{~g} /$ fruit), and reduced the potential for nitrate pollution of groundwater.

\section{Material and methods}

Plant Material and $\mathbf{N}$ FERTILIZER TREATMENTS. The research was conducted in a commercial orchard of 17-year-old 'Hass' avocado trees on 'Duke 7' clonal rootstock located in Somis, CA (lat. $34^{\circ} 15^{\prime} \mathrm{N}$, long. $118^{\circ} 59^{\prime} \mathrm{W}$, elevation $93 \mathrm{~m})$. The orchard soil was Salinas day loam, with $35.7 \%$ sand, $30.8 \%$ silt, $34.5 \%$ clay, and a soil depth greater than $200 \mathrm{~cm}$ (U.S. Department of Agriculture, 2013). The $\mathrm{N}$ treatments were initiated 1.5 years before year 1 of the experiment. All trees received soil-applied $\mathrm{NH}_{4} \mathrm{NO}_{3}$ at $125 \mathrm{lb} /$ acre per year, with the single exception noted below. In treatment 1 , trees received soilapplied $1 \times \mathrm{N}(25 \mathrm{lb} /$ acre $)$ at five stages of tree phenology considered important to crop production based on the results of prior research (mid-month in January, April, July, August, and November) (Table 1). These application times corresponded to the

Table 1. Annual nitrogen (N) fertilizer application times and rates for 'Hass' avocado trees for the four crop years of the research (one crop year is 16 months).

\begin{tabular}{|c|c|c|c|c|c|c|c|c|}
\hline \multirow[b]{2}{*}{ No. } & \multirow{2}{*}{\multicolumn{2}{|c|}{ N Treatment ${ }^{\mathrm{z}}$}} & \multicolumn{6}{|c|}{$\mathrm{N}$ application (lb/acre) } \\
\hline & & & January & April & July & August & November & Annual total \\
\hline 1 & $\begin{array}{l}\text { Ix N January, April, July, } \\
\text { August + November (control) }\end{array}$ & Soil & 25 & 25 & 25 & 25 & 25 & 125 \\
\hline 2 & 2x N April & Soil & 18.75 & 50 & 18.75 & 18.75 & 18.75 & 125 \\
\hline 3 & 2x N April + November & Soil & 8.3 & 50 & 8.3 & 8.3 & 50 & 125 \\
\hline 4 & $2 \mathrm{x}$ N August & Soil & 18.75 & 18.75 & 18.75 & 50 & 18.75 & 125 \\
\hline 7 & $3 x$ N April & Foliar & 12.5 & 75 & 12.5 & 12.5 & 12.5 & 125 \\
\hline 8 & $0.8 x$ N July + August & Soil & - & - & 20 & 20 & - & 40 \\
\hline
\end{tabular}

${ }^{2}$ Soil $=$ soil-applied $\mathrm{N}$ was ammonium nitrate $\left(\mathrm{NH}_{4} \mathrm{NO}_{3}\right)$. Foliar = foliar-applied $\mathrm{N}$ was low-biuret urea (granules, $46 \% \mathrm{~N}, \leq 0.25 \%$ biuret) at $75 \mathrm{lb} / \mathrm{acre}$ in $200 \mathrm{gal} / \mathrm{acre}$ $\left(1,870.8{\left.\mathrm{~L} \cdot h a^{-1}\right)}\right.$ of water (pH 5.5) applied with a 400-psi $(2757.9 \mathrm{kPa})$ handgun sprayer; $1 \mathrm{lb} / \mathrm{acre}=1.1209 \mathrm{~kg} \cdot \mathrm{ha}^{-1}$ 
following stages of tree phenology in the northern hemisphere: January: early bud swell, initiation of flower organ development (Salazar-García et al., 1998); April: anthesis, fruit set, and initiation of spring vegetative shoot growth, including the apical vegetative shoot of indeterminate floral shoots (Salazar-García et al., 1998); July: period of "June" drop for the current crop (Garner and Lovatt, 2008; Garner et al., 2011), initiation of exponential fruit growth and summer vegetative shoot growth (Lovatt, 2001); August: period of exponential fruit growth (Garner and Lovatt, 2008) and initiation of floral development (phase transition) for next spring's bloom (Salazar-García et al., 1998); and November: floral buds are committed to floral development (meristem determined) and end of fall vegetative shoot growth (Salazar-García et al., 1998). For additional reference, fruit size (diameter $\times$ length and weight) ranged as follows for each month of $\mathrm{N}$ fertilizer application for the setting crop: July-10-25 × 14-35 mm, <10 g/fruit; August: $26-43 \times 38-60 \mathrm{~mm}, 25-70 \mathrm{~g} /$ fruit; November: 45-61 × 65-84 mm, 75-175 g/fruit; and January: 48-65 $\times$ 69-90 mm, 80-180 g/fruit (Wang et al., 2016). Although anticipated to be a successful fertilization strategy, treatment 1 was designated the control. Additional treatments included $2 \mathrm{x} \mathrm{N}$ (50 $\mathrm{lb} /$ acre) as $\mathrm{NH}_{4} \mathrm{NO}_{3}$ applied to the soil in (2) April, (3) April plus November, (4) August, and (5) November, (6) $3 \mathrm{x} \mathrm{N}$ (75 lb/acre) as soilapplied $\mathrm{NH}_{4} \mathrm{NO}_{3}$ in April, or (7) $3 \mathrm{x} \mathrm{N}$ as foliar-applied low-biuret urea (granules, $46 \% \mathrm{~N}, \leq 0.25 \%$ biuret) [ $75 \mathrm{lb} /$ acre in $200 \mathrm{gal} /$ acre of water $(5.5 \mathrm{final}$ $\mathrm{pH}$ ), sprayed with a 400-psi handgun sprayer] in April. Trees in treatments 1 to 7 received $125 \mathrm{lb} /$ acre total annual $\mathrm{N}$, with the remaining annual $\mathrm{N}$ for treatments 2 through 7 divided into equal amounts applied to the soil at the same stages of tree phenology (months) the control trees were fertilized. Treatment 8 was soil-applied $0.8 \mathrm{x}$ $\mathrm{N}(20 \mathrm{lb} /$ acre $)$ as $\mathrm{NH}_{4} \mathrm{NO}_{3}$ during July plus again in August $(40 \mathrm{lb} /$ acre total annual N) (Table 1). Treatments were initiated in January. Soil-applied fertilizer was distributed evenly along the intersection of the drip line of the tree and the wetting pattern of the sprinklers in an area $\approx 12$ inches wide on each side of the tree. Fertilizer applications were made toward the end of the irrigation cycle so that the amount of water applied was sufficient to move the fertilizer into the root zone but not significantly beyond it. The experiment was a randomized complete block design with 20 individual trees per treatment. The research was conducted for four crop years (four harvests); the length of time from full bloom to harvest (one crop year) was 16 months.

LEAF NUTRIENT ANALYSES. In September of each year, 20 sixmonth-old spring flush leaves from nonfruiting terminals were collected uniformly around each data tree at $4.5 \mathrm{ft}$ above the ground. Leaves were washed with soapy water and rinsed thoroughly with distilled water, oven dried at $60^{\circ} \mathrm{C}$ for $72 \mathrm{~h}$, and ground in a Wiley mill to pass through a 40 -mesh (0.025-inch) screen (Embleton et al., 1973). The ground samples were sent to Albion Laboratories (Clearfield, UT) for mineral nutrient analysis. For $\mathrm{N}$, samples were combusted at $1050{ }^{\circ} \mathrm{C}$ and $\mathrm{N}$ was determined by thermal conductivity (Leco Corp., St. Joseph, MI). In addition, the concentrations of phosphorus $(\mathrm{P})$, potassium $(\mathrm{K})$, calcium $(\mathrm{Ca})$, magnesium $(\mathrm{Mg})$, sulfur $(\mathrm{S})$, iron $(\mathrm{Fe})$, zinc $(\mathrm{Zn})$, manganese $(\mathrm{Mn})$, boron $(\mathrm{B})$, copper $(\mathrm{Cu})$, molybdenum (Mo), chloride $(\mathrm{Cl})$, and sodium $(\mathrm{Na})$ were determined after nitric acid-hydrogen peroxide microwave digestion by inductively coupled plasma atomic emission spectrometry (Meyer and Keliher, 1992).

YIELD AsSESSMENT. Fruit were harvested annually in August, 16 months after full bloom. The dry matter content of the fruit was greater than the required 20.8\% (Dixon, 2013 ). Total yield was determined as kilograms per tree by removing and weighing all fruit produced by a tree. In addition, at harvest, a randomly selected sample of 100 to 150 fruit/tree, representing $\approx 30 \%$ to $100 \%$ of the mean total number of fruit on a tree for each year of the experiment, was collected for each data tree and the fresh weight of each fruit in the subsample was determined as grams per fruit. These data were used to calculate pack-out, i.e., the kilograms of fruit of each packing carton size per tree and to estimate the total number fruit and number of fruit in each packing carton size category per tree. The following packing carton fruit sizes (grams per fruit) were used 84 (99 to $134 \mathrm{~g}$ ), 70 (135 to $177 \mathrm{~g}$ ), 60 (178 to $212 \mathrm{~g}$ ), 48 $(213$ to $269 \mathrm{~g}), 40(270$ to $325 \mathrm{~g}), 36$ (326 to $354 \mathrm{~g}$ ), and 32 (355 to $397 \mathrm{~g}$ ).
For fruit quality analysis, at each annual harvest, two fruit were selected randomly per tree and allowed to ripen to "eating soft" at 18 to $21^{\circ} \mathrm{C}$. When ripe, external (exocarp) and internal (mesocarp, edible portion) quality was evaluated for decay and discoloration. Vascularization (presence of vascular bundles and associated fibers) of the mesocarp was also determined. The above fruit quality parameters were rated visually on a scale from 0 (normal) to 4 (high incidence of decay, discoloration, or vascularization).

To determine treatment effects on the severity of alternate bearing, the alternate bearing index $(\mathrm{ABI})$ was calculated for each data tree for each pair of consecutive harvests using the following equation: $\mathrm{ABI}=$ (year $\mathrm{l}$ yield - year 2 yield)/(year 1 yield + year 2 yield) in which yield is total kilograms of fruit per tree and the difference in yield between years 1 and 2 is expressed as an absolute value. An ABI of zero means no alternate bearing, whereas an ABI of one is complete alternate bearing (Pearce and Dobersek-Urbanc, 1967).

Temperature and rainfall DATA. Monthly average maximum and minimum air temperatures and rainfall for the four crop years of the research were downloaded from the California Irrigation Management Information System website (California Department of Water Resources, 2009) for the closest station \#152, Camarillo, CA (lat. $34^{\circ} 23^{\prime} \mathrm{W}$, long. $118^{\circ} 99^{\prime} \mathrm{N}$, elevation $76 \mathrm{~m}$ ). Differences in average maximum or minimum temperatures and rainfall for the months corresponding to the key stages in 'Hass' avocado tree phenology were determined for each crop year (January preceding bloom to harvest in August the following year). The relationship of these climate factors to yield was also determined.

N LEACHING ASSESSMENT. Bags of anion-exchange resin Dowex 1-X8 (Sigma Life Sciences, St. Louis, MO) and cation-exchange resin Dowex 50W-X8 (Sigma Life Sciences) were made of nylon cloth $\left(24 \mathrm{~cm}^{2}\right)$. Each bag contained $5.4 \mathrm{~g}$ resin as dry weight. The anion and cation resin bags were prepared in advance in three successive washes with $0.5 \mathrm{M}$ sodium bicarbonate or $0.5 \mathrm{~m}$ hydrochloric acid, respectively, centrifuged in a salad spinner (Tokig), placed in individual zippered plastic bags to prevent 
contamination, and refrigerated at $4{ }^{\circ} \mathrm{C}$ until used. Just before the application of $\mathrm{N}$ to the soil, resin bags (one each of both anion- and cationexchange resin were placed at the lower end of separate polyvinyl chloride pipes, 2.5 inches i.d.) that were placed in the ground at a $45^{\circ}$ angle with the soil surface and at a depth of $75 \mathrm{~cm}$. The pipes were located at the intersection between the drip line of the tree and the wetting pattern of the sprinklers on both sides of each of 10 trees per treatment. The following treatments were sampled at each soil fertilizer application for 2 years: control; $2 \mathrm{x} \mathrm{N}$ in April, August, or November; $3 \mathrm{x} N$ in April; and no $\mathrm{N}$ fertilization to determine $\mathrm{N}$ background levels. The bags were collected $2 \mathrm{~d}$ after $\mathrm{N}$ application and irrigation. New resin bags were used for each fertilizer application. Each resin bag was retrieved from its tube, placed in a labeled individual zippered plastic bag and taken immediately to the laboratory in a cool box. Collected resin bags were rinsed with deionized water to remove adhering soil and the excess water was removed by centrifugation in a salad spinner. Ions were removed from the resin by submerging intact bags in $100 \mathrm{~mL}$ $2.0 \mathrm{M}$ potassium chloride overnight with shaking followed by filtration through Whatman no. 42 filter paper (Thermo Fisher Scientific, Waltham, MA). The sample filtrates were then sent to the University of California Agriculture and Natural Resources Analytical Laboratory (Davis, CA) and analyzed for $\mathrm{NO}_{3}{ }^{-} \mathrm{N}$ (Wendt, 1999) and $\mathrm{NH}_{4}{ }^{+}-\mathrm{N}$ (Switala, 1999).

The concentration of $\mathrm{NO}_{3}^{-}-\mathrm{N}$ was determined, after reduction to nitrite via a $\mathrm{Cu}$-cadmium column, by diazotization with sulfanilamide followed by coupling with $\mathrm{N}$ - (1naphthyl)-ethylenediamine dihydrochloride. The absorbance of the product was measured at $520 \mathrm{~nm}$ (QuickChem Method 10-107-04-1-A; Lachat Instruments, Milwaukee, WI). The $\mathrm{NH}_{4}{ }^{+} \mathrm{N}$ samples were heated with salicylate and hypochlorite in an alkaline phosphate buffer in the presence of ethylenediaminetetraacetic acid to prevent precipitation of $\mathrm{Ca}$ and $\mathrm{Mg}$; sodium nitroprusside was added to enhance the sensitivity of the assay. The absorbance of the reaction product was measured at $630 \mathrm{~nm}$ (QuikChem Method 10-107-06-1-A;
Lachat Instruments). The sensitivity of each method was $\approx 0.05 \mathrm{mg} \cdot \mathrm{L}^{-1}(\mathrm{w} / \mathrm{v})$ for $\mathrm{NO}_{3}^{-}-\mathrm{N}$ and $0.01 \mathrm{mg} \cdot \mathrm{L}^{-1}(\mathrm{w} / \mathrm{v})$ for $\mathrm{NH}_{4}{ }^{+}-\mathrm{N}$ and was reproducible within $7 \%$. Sample filtrates analyzed for $\mathrm{NH}_{4}{ }^{+}-$ $\mathrm{N}$ were also analyzed for total $\mathrm{N}$ and carbon by combustion analysis to quantify the amount of organic matter trapped on the resin bags (Pella, 1990). These results were used to correct the $\mathrm{NH}_{4}{ }^{+}-\mathrm{N}$ samples for this source of $\mathrm{N}$, which did not originate from the fertilizer applications.

Statistical analyses. Repeated measure analysis was used to test for treatment effects on yield parameters, fruit quality, and leaf $\mathrm{N}$ concentrations with year as the repeated measure factor. Repeated measure analysis was also used to test for treatment effects on leachate concentrations of $\mathrm{NO}_{3}^{-}-\mathrm{N}$ and $\mathrm{NH}_{4}{ }^{-} \mathrm{N}$ with sample date as the repeated measure factor. This analysis was performed using the General Linear Models procedure of SAS (version 9.2; SAS Institute, Cary, NC). Analysis of variance (ANOVA) was used to test for treatment effects on leaf concentrations of $\mathrm{N}$ and other nutrients, year effects on climate parameters, amount of $\mathrm{NO}_{3}{ }^{-} \mathrm{N}$ or $\mathrm{NH}_{4}{ }^{+}-\mathrm{N}$ leaching past the root zone in a specific year and as cumulative leachate, and on all yield and fruit quality parameters for a specific year and for cumulative yield. When ANOVA testing indicated significant differences, post hoc comparisons were run using Fisher's protected least significant difference procedure with a family error rate of $\alpha \leq 0.05$. Pearson correlation coefficients were calculated to determine the strength of the relationships between total yield and fruit size and leaf nutrient concentrations and climate factors. Note that for repeated measure analysis and $\mathrm{Cu}^{-}$ mulative yields, a missing datum point for a tree in any year excluded all data for that tree from the statistical analysis.

\section{Results}

Effects of $\mathbf{N}$ fertilizer TREATMENTS ON ANNUAL AND 4-YEAR CUMULATIVE YIELD. Fertilizer strategy had a significant effect on total yield as kilograms per tree in each year of the 4 -year study, but in years 2 and 4 the significance was only at the $10 \%$ level (data not shown). In contrast, the fertilizer treatments significantly impacted total yields as number of fruit per tree only in years 1 and 3 (data not shown). Despite this, trees receiving lx $\mathrm{N}$ at five key stages of tree phenology and trees receiving soil-applied $2 \mathrm{x}$ $\mathrm{N}$ in April or $0.8 \mathrm{x} \mathrm{N}$ in July plus August produced significantly greater 4-year cumulative yields as kilograms per tree than trees receiving foliarapplied 3x N in April or soil-applied $2 \mathrm{x} \mathrm{N}$ in April plus November, but not greater than trees receiving soilapplied $3 \mathrm{x} \mathrm{N}$ in April or $2 \mathrm{x} \mathrm{N}$ in August or November $[P=0.036$ (Table 2)]. As number of fruit per tree, trees receiving soil-applied $2 \mathrm{x} \mathrm{N}$ in April had significantly greater 4-year cumulative yields compared with trees receiving soil-applied $2 \mathrm{x}$ $\mathrm{N}$ in April plus November, $2 \mathrm{x} \mathrm{N}$ in November, and foliar-applied $3 \mathrm{x} \mathrm{N}$ in April, but not greater than trees receiving $1 \mathrm{x} \mathrm{N}$ at five key stages, trees receiving soil-applied $3 \mathrm{x} \mathrm{N}$ in April, $0.8 \mathrm{x} \mathrm{N}$ in July plus August or $2 \mathrm{x} \mathrm{N}$ in August $(P=0.003)$. Trees receiving foliar-applied 3x N in April produced the lowest number of fruit per tree, which was significantly less than trees in all treatments, except soil-applied $2 \mathrm{x}$ $\mathrm{N}$ in April plus November and $2 \mathrm{x} \mathrm{N}$ in November $[P=0.003$ (Table 2)]. Fertilization treatments did not influence yield of CVS fruit (packing carton sizes $60+48+40 ; 178-325 \mathrm{~g} /$ fruit) as kilograms or number of fruit per tree in any year of the research or as 4-year cumulative yield (Table 2). Fertilization treatment had a significant effect on the yield of small fruit (packing carton sizes $84+70 ; 99-177 \mathrm{~g}$ / fruit) in years 1 and 3 as both kilograms and number of fruit per tree (data not shown), which resulted in significant differences in the 4-year cumulative yield of small fruit as both kilograms and number per tree (Table 2). Trees receiving soil-applied $2 \mathrm{x} \mathrm{N}$ in April produced significantly more small fruit as 4-year cumulative yield than trees receiving foliar-applied 3x $\mathrm{N}$ in April or soil-applied 2x N in April plus November, $0.8 \mathrm{x} \mathrm{N}$ in July plus August, and $2 \mathrm{x}$ $\mathrm{N}$ in November as kilograms per tree $(P=0.0003)$ and number of fruit per tree $(P=0.0004)$, but not more small fruit than the control, trees receiving soil-applied $3 \mathrm{x} N$ in April or $2 \mathrm{x} N$ August (Table 2). As total yield increased, yield of CVS fruit and small fruit increased based on kilograms per tree $(r=0.80, P<0.0001$ and $r=0.63, P<0.0001$, respectively) and number of fruit per tree $(r=0.67$, $P<0.0001$ and $r=0.81, P<0.0001$, respectively). 
Table 2. Effects of nitrogen ( $\mathrm{N}$ ) fertilizer application times and rates on 'Hass' avocado 4-year cumulative total yield and yield of commercially valuable size (CVS) fruit (178-325 g/fruit FW) and small fruit (99-177 g/fruit FW) as kilograms and number per tree. ${ }^{\mathrm{z}}$

\begin{tabular}{|c|c|c|c|c|c|c|c|c|}
\hline \multirow[b]{3}{*}{ No. } & \multirow[b]{3}{*}{ N Treatment ${ }^{\mathrm{y}}$} & & \multicolumn{6}{|c|}{ 4-yr cumulative yield ${ }^{\mathrm{z}}$} \\
\hline & & & \multicolumn{2}{|c|}{ Total } & \multicolumn{2}{|c|}{ CVS fruit } & \multicolumn{2}{|c|}{ Small fruit } \\
\hline & & & (kg/tree) & (no./tree) & (kg/tree) & (no./tree) & (kg/tree) & (no./tree) \\
\hline 2 & $2 \mathrm{x}$ N April & Soil & 249.9 a & $1,338 \mathrm{a}$ & $144.2 \mathrm{a}$ & $646 a$ & 99.8 a & $675 \mathrm{a}$ \\
\hline 3 & 2x N April + November & Soil & $208.0 \mathrm{~b}$ & $1,062 \mathrm{bc}$ & $134.9 \mathrm{a}$ & 595 a & $65.6 \mathrm{~b}$ & $446 \mathrm{~b}$ \\
\hline 6 & $3 x$ N April & Soil & $235.2 \mathrm{ab}$ & $1,196 \mathrm{ab}$ & $151.2 \mathrm{a}$ & $666 a$ & $74.5 \mathrm{ab}$ & $503 \mathrm{ab}$ \\
\hline 7 & $3 x$ N April & Foliar & $208.1 \mathrm{~b}$ & $946 \mathrm{c}$ & $160.2 \mathrm{a}$ & $682 \mathrm{a}$ & $33.5 \mathrm{c}$ & $223 c$ \\
\hline 8 & $0.8 \mathrm{x}$ N July + August & Soil & $241.6 \mathrm{a}$ & $1,181 \mathrm{ab}$ & $173.6 \mathrm{a}$ & $764 \mathrm{a}$ & $58.6 \mathrm{bc}$ & 390 bc \\
\hline \multicolumn{3}{|c|}{$P$ value } & 0.0362 & 0.0026 & 0.1451 & 0.1465 & 0.0003 & 0.0004 \\
\hline
\end{tabular}

${ }^{\mathrm{z}} \mathrm{lg}=0.0353 \mathrm{oz}, \mathrm{l} \mathrm{kg}=2.2046 \mathrm{lb}, 1 \mathrm{lb}=0.4536 \mathrm{~kg} ;$ commercially valuable size fruit and small fruit correspond to packing carton sizes $60+48+40$ and $84+70$, respectively; packing carton size is based on the number of fruit per 25 -lb box within a tolerance of $0.5 \mathrm{lb}$.

${ }^{y}$ Refer to Table 1 .

${ }^{x}$ Means in a vertical column followed by different letters are significantly different by Fisher's protected least significant difference test at $P \leq 0.05$. See table 3 for accuracy.

Table 3. Effects of nitrogen (N) fertilizer application times and rates on 'Hass' avocado leaf $\mathrm{N}$ concentrations in year 4 and averaged across the four crop years of the research; one crop year is 16 months.

\begin{tabular}{|c|c|c|c|c|}
\hline \multirow[b]{2}{*}{ No. } & \multirow[b]{2}{*}{ N Treatment ${ }^{\mathrm{z}}$} & & \multicolumn{2}{|c|}{ Leaf $N$ concn $(g / 100 \mathrm{~g} \text { leaf tissue } D W)^{y}$} \\
\hline & & & Yr 4 & 4 4-yr avg \\
\hline 1 & $\begin{array}{l}\text { Ix N January, April, July, } \\
\text { August + November (control }\end{array}$ & Soil & $2.37 \mathrm{abc}^{\mathrm{x}}$ & $2.56 \mathrm{ab}$ \\
\hline 2 & 2x N April & Soil & $2.32 \mathrm{bc}$ & $2.55 \mathrm{ab}$ \\
\hline 3 & 2x N April + November & Soil & $2.33 \mathrm{bc}$ & $2.53 \mathrm{bc}$ \\
\hline 4 & 2x N August & Soil & $2.31 \mathrm{bc}$ & $2.57 \mathrm{ab}$ \\
\hline 5 & 2x N November & Soil & $2.37 \mathrm{abc}$ & $2.58 \mathrm{ab}$ \\
\hline 6 & $3 \mathrm{x}$ N April & Soil & $2.45 \mathrm{a}$ & $2.62 \mathrm{a}$ \\
\hline 7 & $3 x$ N April & Foliar & $2.38 \mathrm{ab}$ & $2.59 \mathrm{ab}$ \\
\hline 8 & $0.8 \mathrm{x}$ N July + August & Soil & $2.28 \mathrm{c}$ & $2.46 \mathrm{c}$ \\
\hline$P$ va & lue & & 0.0270 & 0.0284 \\
\hline
\end{tabular}

${ }^{2}$ Refer to Table 1 .

${ }^{y} \mathrm{lg} / 100 \mathrm{~g}=1 \%$.

${ }^{x}$ Means in a vertical column followed by different letters are significantly different by Fisher's protected least significant difference test at $P \leq 0.05$.

EFFECT OF N FERTILIZER TREATMENTS ON TREE NUTRIENT STATUS. Nitrogen fertilization strategy had no effect on leaf $\mathrm{N}$ concentration until year 4 of the research. By year 4, trees receiving soil-applied $3 \mathrm{x} N$ in April accumulated leaf $\mathrm{N}$ concentrations that were significantly greater than trees receiving soil-applied $2 \mathrm{x} \mathrm{N}$ in April, 2x $\mathrm{N}$ in April plus November, $0.8 \times \mathrm{N}$ in July plus August, and $2 \mathrm{x} \mathrm{N}$ in August $(P=0.027)$, but control trees and trees receiving foliar-applied $3 \times \mathrm{N}$ in April or soilapplied 2x $\mathrm{N}$ in November had leaf $\mathrm{N}$ concentrations that were intermediate and not significantly different (Table 3 ). Trees receiving only $0.8 x$ $\mathrm{N}$ in July plus August had the lowest leaf $\mathrm{N}$ concentration but it was not significantly lower than that of the control trees or trees receiving soilapplied 2x $\mathrm{N}$ in April, 2x $\mathrm{N}$ in April and November, and $2 \mathrm{x} \mathrm{N}$ in August or $2 \mathrm{x} \mathrm{N}$ in November. Repeated measure analysis documented an annual decrease in leaf $\mathrm{N}$ values from year 1 to year $4(P<0.0001)$ (data not shown). Trees receiving soilapplied 3x N in April had the greatest 4-year average leaf $\mathrm{N}$ concentration, which was significantly greater than trees receiving soil-applied $2 \mathrm{x} N$ in April plus November and $0.8 \mathrm{x} \mathrm{N}$ in July plus August, but not greater than other treatments $[P=0.028$ (Table 3)]. Trees receiving soil-applied $0.8 \mathrm{x} \mathrm{N}$ in July plus August had the lowest 4-year average leaf $\mathrm{N}$ concentration, but not lower than trees treated with soilapplied 2x N in April and November (Table 3). All trees in all treatments in all years had leaf $\mathrm{N}$ concentrations that were greater than the $2.2 \%$ recommended by the California Avocado Commission (Lovatt and Witney, 2001). There was a weak but significant relationship between leaf $\mathrm{N}$ concentration and total yield as kilograms and number of fruit per tree $(r=0.29, P<$ 0.0001 and $r=0.22, P<0.0007$, respectively) and yield of CVS fruit as kilograms and number of fruit per tree (for both $r=0.38, P<0.0001$ ). Interestingly, yield of small fruit was not related to leaf $\mathrm{N}$ concentration as kilograms or number of fruit per tree.

Leaf $\mathrm{P}, \mathrm{K}, \mathrm{Ca}, \mathrm{Mg}, \mathrm{S}, \mathrm{Fe}, \mathrm{Zn}$, $\mathrm{Mn}, \mathrm{B}$, and $\mathrm{Cu}$ concentrations were all within the ranges considered optimal for avocado in California (data not shown) (Jones and Embleton, 1978). There is no recommendation for Mo, but leaf concentrations of Mo were not significantly different across treatments and years. Both $\mathrm{Cl}$ and $\mathrm{Na}$ were below the levels considered toxic to avocado (Jones and Embleton, 1978). Nitrogen fertilization strategy had a significant effect only on leaf concentrations of S, Mn, and Fe and only in the first 2 years of the research. In year 1 , trees receiving $0.8 \mathrm{x} \mathrm{N}$ in July plus August had a significantly greater leaf $S$ concentration than trees in all other treatments $(P=0.05)$. In contrast, trees receiving $0.8 \mathrm{x} \mathrm{N}$ in July plus August or foliar-applied $3 \mathrm{x}$ $\mathrm{N}$ in April had equal leaf Mn concentrations that were significantly lower than trees in all other treatments $(P<$ $0.0001)$. In year 2 , there continued to be an $\mathrm{N}$ fertilizer effect on leaf $\mathrm{S}(\mathrm{P}=$ $0.002)$ and $\mathrm{Mn}(P<0.0001)$, with an 
Table 4. Effects of nitrogen $(\mathrm{N})$ fertilizer application times and rates on the alternate bearing index (ABI) of 'Hass' avocado trees for the four harvests in the research.

\begin{tabular}{|c|c|c|c|c|c|c|}
\hline \multirow[b]{2}{*}{ No. } & \multirow[b]{2}{*}{$\mathbf{N}$ treatment $^{\mathrm{z}}$} & & \multicolumn{4}{|c|}{$\mathrm{ABI}^{\mathrm{y}}$} \\
\hline & & & Yrs 1 and 2 & Yrs 2 and 3 & Yrs 3 and 4 & 4-yr avg \\
\hline 1 & $\begin{array}{l}\text { lx N January, } \\
\text { April, July, } \\
\text { August + November } \\
\text { (control) }\end{array}$ & Soil & $0.47 \mathrm{abc}^{\mathrm{x}}$ & $0.62 \mathrm{ab}$ & $0.46 \mathrm{a}$ & $0.52 \mathrm{abc}$ \\
\hline 2 & $2 \mathrm{x} \mathrm{N}$ April & Soil & $0.60 \mathrm{a}$ & $0.67 \mathrm{a}$ & $0.55 \mathrm{a}$ & $0.61 \mathrm{a}$ \\
\hline 3 & $\begin{array}{l}\text { 2x N April }+ \\
\text { November }\end{array}$ & Soil & $0.47 \mathrm{abc}$ & $0.43 \mathrm{c}$ & $0.40 \mathrm{a}$ & $0.43 \mathrm{bc}$ \\
\hline 4 & 2x N August & Soil & $0.50 \mathrm{abc}$ & $0.46 \mathrm{bc}$ & $0.46 \mathrm{a}$ & $0.47 \mathrm{bc}$ \\
\hline 5 & 2x N November & Soil & $0.54 \mathrm{ab}$ & $0.47 \mathrm{bc}$ & $0.59 \mathrm{a}$ & $0.53 \mathrm{ab}$ \\
\hline 6 & 3x N April & Soil & $0.42 \mathrm{bc}$ & $0.41 \mathrm{c}$ & $0.36 \mathrm{a}$ & $0.40 \mathrm{c}$ \\
\hline 7 & $3 x$ N April & Foliar & $0.33 \mathrm{c}$ & $0.43 \mathrm{c}$ & $0.47 \mathrm{a}$ & $0.41 \mathrm{bc}$ \\
\hline 8 & $0.8 x$ N July + August & Soil & $0.52 \mathrm{ab}$ & $0.50 \mathrm{abc}$ & $0.33 \mathrm{a}$ & $0.45 \mathrm{bc}$ \\
\hline \multicolumn{2}{|c|}{$P$ value } & & 0.0868 & 0.0492 & 0.1251 & 0.0387 \\
\hline
\end{tabular}

${ }^{2}$ Refer to Table 1 .

${ }^{y} \mathrm{ABI}=($ year 1 yield - year 2 yield $) /($ year 1 yield + year 2 yield $)$ in which yield is total kilograms of fruit per tree and the difference in yield between years 1 and 2 is expressed as an absolute value; an ABI of zero means no alternate bearing, an $\mathrm{ABI}$ of one means complete alternate bearing.

${ }^{x}$ Means in a vertical column followed by different letters are significantly different by Fisher's protected least significant difference test at $P \leq 0.05$.

additional effect on leaf $\mathrm{Fe}(P=0.01)$ concentration. Trees treated with soil-applied 2x $\mathrm{N}$ in April plus November had a leaf Fe concentration greater than trees receiving soilapplied 2x N in April, 2x N in August, and $0.8 \mathrm{x} \mathrm{N}$ in July plus August, but control trees, trees receiving soilapplied 2x $\mathrm{N}$ in November, and soilor foliar-applied $3 \mathrm{x} \mathrm{N}$ in April had intermediate leaf $\mathrm{Fe}$ concentrations that were not significantly different from all other treatments. Despite these $\mathrm{N}$ fertilizer effects, leaf concentrations of $\mathrm{S}, \mathrm{Mn}$, and Fe were always with the optimum range for avocado and there was no significant relationship between the leaf concentrations of S, $\mathrm{Mn}$, or Fe and total yield or yield of CVS fruit or small fruit in years 1 and 2 , respectively.

EFfects OF Climate AND $\mathbf{N}$ FERTILIZER TREATMENTS ON ALTERNATE BEARING AND 4-YEAR AVERAGE YIELD. There were no significant differences in average maximum or minimum temperatures during key stages of 'Hass' avocado tree phenology during the four crop years of the research. Rainfall was significantly greater from prebloom in January to the end of bloom (part of fruit set) in May in year 2 than in years 1 and 3 , but only by 2.2 inches over the 5 months, and thus, likely of little consequence in the irrigated orchard; year 4 rainfall during this period was intermediate and not significantly from the other years $(P=0.259)$. Annual average rainfall during key stages of avocado tree phenology did not correlate with annual yield parameters. Thus, the ABI for the orchard was unaffected by these climatic factors during the four crop years of the research. The ABI for the orchard was moderate, averaging $0.48,0.50$, and 0.45 across treatments for years 1 to 2,2 to 3 , and 3 to 4 , respectively (Table 4). In contrast, $\mathrm{N}$ fertilizer strategies tested in this experiment significantly influenced the ABI for crop years 2 to 3 (Table 4 ). Although the relative effects of each $\mathrm{N}$ strategy on ABI varied from year to year, there was a significant effect of $\mathrm{N}$ treatment on 4-year average ABI $(P=0.039)$. Trees receiving soil-applied $2 \mathrm{x} \mathrm{N}$ in April had the highest 4-year average ABI, which was significantly greater than trees in all treatments, except the control and trees receiving $2 \mathrm{x} \mathrm{N}$ in November $(P=0.039)$.

Despite the facts that the orchard was alternate bearing, with significant differences in yield from year to year, and that $\mathrm{N}$ fertilizer treatments affected the degree of alternate bearing in the orchard, it is noteworthy that $\mathrm{N}$ fertilization treatment had a significant effect on total yield as both kilograms and number of fruit per tree when averaged across the 4 years of the experiment. Results of the repeated measure analysis identified $\mathrm{N}$ treatments that had a positive effect on total yield annually, indicating that significant increases in cumulative yield were not solely the result of the on-crop years due to alternate bearing (Table 5). Control trees and trees receiving soil-applied $2 \mathrm{x} \mathrm{N}$ in April produced greater 4-year average yields as kilograms per tree than trees receiving foliar-applied $3 \mathrm{x} \mathrm{N}$ in April and soil-applied 2x $\mathrm{N}$ in April plus November $(P=0.031)$, with trees in all other treatments producing intermediate yields that were not significantly different. Only trees receiving soil-applied 2x $\mathrm{N}$ in April produced 4-year average yields as number of fruit per tree that were significantly greater than trees receiving foliar $3 \mathrm{x}$ $\mathrm{N}$ in April or soil-applied $2 \mathrm{x} \mathrm{N}$ in April plus November, and $2 \mathrm{x} \mathrm{N}$ in November $(P=0.002)$. Trees receiving foliar 3x $\mathrm{N}$ in April produced the lowest 4-year average number of fruit per tree, which was significantly lower than that of the other treatments except soil-applied 2x $\mathrm{N}$ in April plus November and 2x $\mathrm{N}$ in November. Year was a significant factor influencing total yield as both kilograms and number of fruit per tree $(P<0.0001)$ and there was a significant treatment and year interaction influencing total yield as kilograms per tree $(P=0.032)$ and number of fruit per tree $(P=$ $0.036)$. Year was the only factor affecting the 4-year average yield of CVS fruit as kilograms $(P<0.0001)$ and number of fruit per tree $[P<$ 0.0001 (Table 5$)$ ]. In contrast, there was a significant effect due to $\mathrm{N}$ fertilization strategy on the 4-year average yield of small fruit as both kilograms $(P=0.0002)$ and number $(P=0.0003)$ per tree (Table 5$)$. In both cases, trees receiving soil-applied $2 \mathrm{x} \mathrm{N}$ in April produced more small fruit as both kilograms and number per tree than trees receiving soilapplied 2x N in April plus November, $0.8 \mathrm{x} \mathrm{N}$ in July plus August, $2 \mathrm{x} \mathrm{N}$ in November, and foliar-applied $3 \mathrm{x} \mathrm{N}$ in April, but not more than the control trees, trees receiving soil-applied $3 \mathrm{x} N$ in April or 2x N in August (Table 5 ). Although trees receiving foliarapplied 3x $\mathrm{N}$ in April produced the least small fruit, it was not less than trees treated with soil-applied $0.8 \mathrm{x} \mathrm{N}$ in July plus August or $2 \mathrm{x} \mathrm{N}$ in $\mathrm{No}^{-}$ vember. Year strongly influenced the yield of small fruit as both kilograms $(P<0.0001)$ and number of fruit per tree $(P<0.0001)$ and there was 
Table 5. Effects of nitrogen $(\mathrm{N})$ fertilizer application times and rates on 'Hass' avocado 4-year average total yield and yield of commercially valuable size (CVS) fruit (178-325 g/fruit FW) and small fruit (99-177 g/fruit FW) as kilograms and number per tree. ${ }^{\mathrm{z}}$

\begin{tabular}{|c|c|c|c|c|c|c|c|c|}
\hline \multirow[b]{3}{*}{ No. } & \multirow[b]{3}{*}{ N treatment ${ }^{\mathrm{y}}$} & & \multicolumn{6}{|c|}{ 4-yr avg yield ${ }^{z}$} \\
\hline & & & \multicolumn{2}{|c|}{ Total } & \multicolumn{2}{|c|}{ CVS fruit } & \multicolumn{2}{|c|}{ Small fruit } \\
\hline & & & (kg/tree) & (no./tree) & (kg/tree) & (no./tree) & (kg/tree) & (no./tree) \\
\hline 2 & 2x N April & Soil & $62.5 \mathrm{a}$ & $335 \mathrm{a}$ & $36.0 \mathrm{a}$ & $162 \mathrm{a}$ & $25.0 \mathrm{a}$ & 169 a \\
\hline 3 & 2x N April + November & Soil & $52.0 \mathrm{~b}$ & $266 \mathrm{bc}$ & $33.7 \mathrm{a}$ & $149 \mathrm{a}$ & $16.4 \mathrm{~b}$ & $112 \mathrm{~b}$ \\
\hline 6 & 3x N April & Soil & $58.8 \mathrm{ab}$ & $299 \mathrm{ab}$ & $37.8 \mathrm{a}$ & $167 \mathrm{a}$ & $18.6 \mathrm{ab}$ & $126 \mathrm{ab}$ \\
\hline 7 & $3 x$ N April & Foliar & $52.0 \mathrm{~b}$ & $236 c$ & $40.0 \mathrm{a}$ & $171 \mathrm{a}$ & $8.4 \mathrm{c}$ & $56 \mathrm{c}$ \\
\hline 8 & $\begin{array}{l}0.8 x \text { N July + August } \\
\text { Year }\end{array}$ & Soil & $60.4 \mathrm{ab}$ & $295 \mathrm{ab}$ & $43.4 \mathrm{a}$ & $191 \mathrm{a}$ & $14.7 \mathrm{bc}$ & 98 bc \\
\hline & 1 & & $84.5 \mathrm{a}$ & $432 \mathrm{a}$ & $61.2 \mathrm{a}$ & $280 \mathrm{a}$ & $22.8 \mathrm{~b}$ & $151 \mathrm{~b}$ \\
\hline & Treatment $(\mathrm{T})$ & & 0.0305 & 0.0016 & 0.1711 & 0.1824 & 0.0002 & 0.0003 \\
\hline & Year $(\mathrm{Y})$ & & $<0.0001$ & $<0.0001$ & $<0.0001$ & $<0.0001$ & $<0.0001$ & $<0.0001$ \\
\hline & $\mathrm{T} \times \mathrm{Y}$ & & 0.0323 & 0.0356 & 0.2113 & 0.1854 & 0.0291 & 0.0366 \\
\hline
\end{tabular}

${ }^{\mathrm{z}} \mathrm{lg}=0.0353 \mathrm{oz}, \mathrm{l} \mathrm{kg}=2.2046 \mathrm{lb}, \mathrm{l} \mathrm{lb}=0.4536 \mathrm{~kg} ;$ commercially valuable size fruit and small fruit correspond to packing carton sizes $60+48+40$ and $84+70$, respectively; packing carton size is based on the number of fruit per 25 -lb box within a tolerance of $\pm 0.5 \mathrm{lb}$.

'Refer to Table 1.

${ }^{x}$ Means in a vertical column followed by different letters are significantly different by Fisher's protected least significant difference test at $P \leq 0.05$.

a strong interaction between $\mathrm{N}$ fertilization treatment and year that impacted the 4-year average yield of small fruit as kilograms $(P=0.029)$ and number of fruit $(P=0.037)$ per tree (Table 5 ).

EFFECT OF $\mathbf{N}$ FERTILIZER TREATMENTS ON FRUIT QUALITY. Vascularization, the presence of vascular bundles and associated fibers in the mesocarp, was the only fruit quality parameter affected by $\mathrm{N}$ fertilization treatment when averaged across the 4 years of the research (Table 6 ). The mesocarp of fruit from control trees had a significantly greater incidence of vascularization than fruit from trees in all other treatments except soil-applied 2x $\mathrm{N}$ in November, which had a level of vascularization equal to that of fruit from all other treatments except foliar-applied $3 \mathrm{x} \mathrm{N}$ in April $(P=0.007)$. The annual incidence of vascularization, discoloration, and decay were low, but significantly influenced by year $(P<0.0001)$. It is unknown whether the effect of year was related to alternate bearing and crop load or due to annual differences in climate. There were no significant treatment and year interactions that affected any fruit quality parameter for the 4 years of the research.
EFFECT OF $\mathbf{N}$ FERTILIZER TREATMENTS ON $\mathbf{N}$ LEACHING PAST THE ROOT ZONE. There were no significant effects of $\mathrm{N}$ fertilization strategy on the amount of $\mathrm{N}$ leaching past the root zone quantified as $\mathrm{NO}_{3}{ }^{-}-\mathrm{N}$ or $\mathrm{NH}_{4}{ }^{+}-\mathrm{N}$ for any sample date in years 1 or 2 of the research or as the cumulative amount for year 1 or 2 (data not shown). There were no $\mathrm{N}$ treatment effects on the amount of $\mathrm{NO}_{3}{ }^{-}-\mathrm{N}$ or $\mathrm{NH}_{4}{ }^{+}-\mathrm{N}$ leaching past the root zone averaged across the first 2 years of the research (Table 7 ). However, sample date had a significant effect on the amount of $\mathrm{NH}_{4}{ }^{+}-\mathrm{N}$ leaching past the root zone $(P<$ $0.0001)$.

\section{Discussion}

Nitrogen fertilization treatments were tested with the objectives of increasing total yield of the 'Hass' avocado without reducing fruit size or increasing the potential for groundwater contamination by $\mathrm{NO}_{3}^{-}-\mathrm{N}$ or $\mathrm{NH}_{4}{ }^{+}-\mathrm{N}$. The results of this research provide strong evidence that soil $\mathrm{N}$ application time is an important factor influencing 'Hass' avocado yield. There were no significant differences in 4-year cumulative or 4-year average total yields or yields of CVS fruit (as kilograms per tree) for trees receiving a single dose of $\mathrm{N}$ at the five key stages of tree phenology described in the methods (control) vs. trees receiving a double dose of $\mathrm{N}$ ( $50 \mathrm{lb} /$ acre $)$ at one key stage of tree phenology and only $18.75 \mathrm{lb} /$ acre $\mathrm{N}$ instead of $25 \mathrm{lb} /$ acre $\mathrm{N}$ at the four other phenological stages. On the basis of this, the five $1 \mathrm{x} N$ soil applications of $\mathrm{N}$ would be the preferred fertilization practice compared with providing $2 \mathrm{x} \mathrm{N}$ in a single soil application due to the possible increased potential for nitrate pollution of the groundwater. However, control trees did not have significantly lower amounts of $\mathrm{NO}_{3}{ }^{-}-\mathrm{N}$ or $\mathrm{NH}_{4}{ }^{+}-\mathrm{N}$ leaching past the root zone. In contrast, 4-year cumulative and 4-year average total yields were significantly lower than the control and trees receiving soilapplied $2 \mathrm{x} \mathrm{N}$ in April when trees received foliar-applied $3 \mathrm{x} \mathrm{N}$ in April, but not soil-applied $3 x \mathrm{~N}$ in April. The results suggest that the high rate of urea had a toxic effect when applied to the canopy during flowering and fruit set that did not occur when $3 \mathrm{x} \mathrm{N}$ as $\mathrm{NH}_{4} \mathrm{NO}_{3}$ was applied to the soil during this stage of tree phenology. Yield and fruit size of trees receiving soil-applied $3 \mathrm{x} N$ were not significantly reduced, which also suggests that supplying only 
Table 6. Effects of nitrogen $(\mathrm{N})$ fertilizer application times and rates on 'Hass' avocado fruit quality parameters averaged across the four harvests in the research.

\begin{tabular}{|c|c|c|c|c|c|c|}
\hline \multirow[b]{2}{*}{ No. } & \multirow{2}{*}{\multicolumn{2}{|c|}{$\mathbf{N}$ treatment $^{\mathrm{z}}$}} & \multirow[b]{2}{*}{ Time to ripen (d) } & \multicolumn{3}{|c|}{ Fruit quality $(0-4 \text { scale })^{\mathrm{y}}$} \\
\hline & & & & Vascularization & Discoloration & Decay \\
\hline 1 & $\begin{array}{l}\text { lx N January, April, July, } \\
\text { August + November (control) }\end{array}$ & Soil $^{y}$ & $11.1 \mathrm{a}^{\mathrm{x}}$ & $0.3 \mathrm{a}$ & $0.1 \mathrm{a}$ & $0.1 \mathrm{a}$ \\
\hline 2 & 2x N April & Soil & $11.0 \mathrm{a}$ & $0.1 \mathrm{bc}$ & $0.0 \mathrm{a}$ & $0.1 \mathrm{a}$ \\
\hline 3 & 2x N April + November & Soil & $10.4 \mathrm{a}$ & $0.2 \mathrm{bc}$ & $0.1 \mathrm{a}$ & $0.2 \mathrm{a}$ \\
\hline 4 & 2x N August & Soil & $11.0 \mathrm{a}$ & $0.2 \mathrm{bc}$ & $0.1 \mathrm{a}$ & $0.1 \mathrm{a}$ \\
\hline 5 & 2x N November & Soil & $10.7 \mathrm{a}$ & $0.2 \mathrm{ab}$ & $0.1 \mathrm{a}$ & $0.1 \mathrm{a}$ \\
\hline 6 & 3x N April & Soil & $10.4 \mathrm{a}$ & $0.1 \mathrm{c}$ & $0.1 \mathrm{a}$ & $0.1 \mathrm{a}$ \\
\hline 7 & $3 x$ N April & Foliar ${ }^{v}$ & $10.5 \mathrm{a}$ & $0.1 \mathrm{bc}$ & $0.1 \mathrm{a}$ & $0.1 \mathrm{a}$ \\
\hline \multirow[t]{10}{*}{8} & $0.8 \mathrm{x}$ N July + August & Soil & $10.6 \mathrm{a}$ & $0.2 \mathrm{bc}$ & $0.1 \mathrm{a}$ & $0.1 \mathrm{a}$ \\
\hline & Year & & & & & \\
\hline & 1 & & - $\mathrm{w}$ & $0.1 \mathrm{c}$ & $0.0 \mathrm{~b}$ & $0.0 \mathrm{~b}$ \\
\hline & 2 & & - & $0.1 \mathrm{c}$ & $0.0 \mathrm{~b}$ & $0.1 \mathrm{~b}$ \\
\hline & 3 & & $12.2 \mathrm{a}$ & $0.3 \mathrm{a}$ & $0.0 \mathrm{~b}$ & $0.3 \mathrm{a}$ \\
\hline & 4 & & $9.1 \mathrm{~b}$ & $0.2 \mathrm{~b}$ & $0.2 \mathrm{a}$ & $0.1 \mathrm{~b}$ \\
\hline & $P$ value & & & & & \\
\hline & Treatment $(\mathrm{T})$ & & 0.7037 & 0.0073 & 0.4542 & 0.9240 \\
\hline & Year $(\mathrm{Y})$ & & $<0.0001$ & $<0.0001$ & $<0.0001$ & $<0.0001$ \\
\hline & $\mathrm{T} \times \mathrm{Y}$ & & 0.1111 & 0.1235 & 0.9468 & 0.9829 \\
\hline
\end{tabular}

${ }^{2}$ Refer to Table 1 .

${ }^{y}$ Fruit quality parameters were rated visually on a scale from 0 (normal) to 4 (high incidence of vascularization, discoloration or decay of the mesocarp, and edible portion of the fruit).

${ }^{x}$ Means in a vertical column followed by different letters are significantly different by Fisher's protected least significant difference test at $P \leq 0.05$.

"Missing data.

Table 7. Effects of nitrogen $(\mathrm{N})$ fertilizer application times and rates on the amount of nitrate- $\mathrm{N}\left(\mathrm{NO}_{3}{ }^{-}-\mathrm{N}\right)$ and ammonium- $\mathrm{N}\left(\mathrm{NH}_{4}{ }^{+}-\mathrm{N}\right)$ leaching past the root zone of 'Hass' avocado trees averaged across the first 2 years of the research.

\begin{tabular}{|c|c|c|c|c|}
\hline No. & \multicolumn{2}{|l|}{$\mathrm{N}$ treatment $^{\mathrm{z}}$} & $\begin{array}{c}\mathrm{NO}_{3}{ }^{-}-\mathrm{N}\left(\mu \mathrm{g} \cdot \mathrm{g}^{-1}\right. \\
\text { resin } \mathrm{DW})^{\mathrm{y}} \\
\end{array}$ & $\begin{array}{c}\mathrm{NH}_{4}{ }^{+}-\mathrm{N}\left(\mu \mathrm{g} \cdot \mathrm{g}^{-1}\right. \\
\text { resin } \mathrm{DW}) \\
\end{array}$ \\
\hline 1 & $\begin{array}{l}\text { 1x N January, } \\
\text { April, July, } \\
\text { August + November } \\
\text { (control) }\end{array}$ & Soil & $239 a^{x}$ & 38 a \\
\hline 2 & $2 \mathrm{x}$ N April & Soil & $463 \mathrm{a}$ & $40 \mathrm{a}$ \\
\hline 3 & 2x N August & Soil & 547 a & $55 \mathrm{a}$ \\
\hline 4 & 2x N November & Soil & $820 \mathrm{a}$ & $40 \mathrm{a}$ \\
\hline \multirow[t]{11}{*}{5} & $\begin{array}{l}3 \mathrm{x} N \text { April } \\
\text { Sample date }\end{array}$ & Soil & $677 \mathrm{a}$ & 38 a \\
\hline & April year 1 & & $727 \mathrm{a}$ & $94 \mathrm{a}$ \\
\hline & August year 1 & & $-^{\mathrm{w}}$ & - \\
\hline & November year 1 & & $625 \mathrm{a}$ & $18 \mathrm{c}$ \\
\hline & April year 2 & & $608 \mathrm{a}$ & $50 \mathrm{~b}$ \\
\hline & August year 2 & & $709 \mathrm{a}$ & $32 \mathrm{bc}$ \\
\hline & November year 2 & & $251 \mathrm{a}$ & $21 \mathrm{c}$ \\
\hline & $P$ value & & & \\
\hline & Treatment $(\mathrm{T})$ & & 0.9517 & 0.6363 \\
\hline & Sample date (SD) & & 0.7589 & $<0.0001$ \\
\hline & $\mathrm{T} \times \mathrm{SD}$ & & 0.2976 & 0.9890 \\
\hline
\end{tabular}

${ }^{2}$ Refer to Table 1 .

${ }^{y} 1 \mu \mathrm{g} \cdot \mathrm{g}^{-1}=1 \mathrm{ppm}$.

'Means in a vertical column followed by different letters are significantly different by Fisher's protected least significant difference test at $P \leq 0.05$.

"Missing data.

$12.5 \mathrm{lb} /$ acre $\mathrm{N}$ at each of the four other key phenological stages was sufficient, at least over the 4 years of this research. In contrast, the reductions in 4-year cumulative and average total yields associated with soil-applied $2 \mathrm{x} \mathrm{N}$ in April plus November suggest that supplying $8.3 \mathrm{lb} /$ acre $\mathrm{N}$ at each of the remaining three phenological stages was insufficient to maintain yield and fruit size. In particular, these trees would have received only $8.3 \mathrm{lb} /$ acre $\mathrm{N}$ in July and August. For comparison, trees receiving $0.8 \mathrm{x} \mathrm{N}(20 \mathrm{lb} /$ acre N) only in July plus August (40 $\mathrm{lb} /$ acre total annual $\mathrm{N}$ ) had 4-year cumulative and 4-year average total yields and yields of CVS fruit equal to those of the control trees and trees receiving soil-applied $2 \mathrm{x} \mathrm{N}$ in April over the 4 years of the research. This result supports the hypothesis that it is important to meet the $\mathrm{N}$ demand of the multiple physiological and developmental process that occur concurrently in 'Hass' avocado tree phenology during the summer, the major period of $\mathrm{N}$ uptake by the fruit (Rosecrance et al., 2012). It should also be noted that soil-applied $2 \mathrm{x} \mathrm{N}$ in August produced similar yield results as $0.8 \mathrm{x} \mathrm{N}$ in July plus August. June drop for the developing fruit occurs from mid-June through August in California (Garner and Lovatt, 2008; Garner et al., 2011). Summer vegetative shoot growth and exponential fruit growth occur in July through August (Lovatt, 2011). In addition, the end of July to beginning of August is when abscission of the mature fruit begins (Garner and Lovatt, 2008; Garner et al., 2011) and inflorescence initiation for next year's crop takes place (Salazar-García et al., 1998). 
Insufficient $\mathrm{N}$ to meet the needs of the developing fruit, mature fruit, and summer vegetative shoot growth during this time would not only contribute to yield loss and reduced fruit size, but also contribute to alternate bearing. Summer vegetative shoots contribute $\approx 60 \%$ to $70 \%$ of the total inflorescences at spring bloom the following year in California (Lovatt, 2011). Taken together, these results indicate that $\mathrm{N}$ fertilizer should be applied to the soil during the summer at an adequate rate to mitigate June drop and support the competing growth processes of the fruit and summer vegetative shoots in a $\mathrm{N}$ BMP developed for 'Hass' avocado.

Vascularization of the mesocarp (edible portion of the fruit) was the only fruit quality parameter affected by $\mathrm{N}$ treatment. Control trees had significantly more vascularization of the mesocarp than trees in all other treatments, except trees receiving soil-applied $2 \mathrm{x} \mathrm{N}$ in November. However, the incidence of vascularization of the mesocarp for fruit from control trees was only 0.3 on a scale from 0 to 4 and thus likely physiologically insignificant.

All $\mathrm{N}$ fertilization treatments were implemented in the orchard 1.5 years before the start of the experiment. However, in year 1 of the experiment, leaf $\mathrm{N}$ concentrations averaged $2.71 \%$ across trees in all treatments, suggesting that previous $\mathrm{N}$ fertilization rates used in this orchard might have been greater than those used in the research presented herein. By year 4 of the experiment, leaf $\mathrm{N}$ values for trees in all treatments decreased to an average of $2.35 \%$. The results indicate that residual soil $\mathrm{N}$ was decreasing with time. Consistent with this interpretation, the amount of $\mathrm{NO}_{3}{ }^{-} \mathrm{N}$ and $\mathrm{NH}_{4}{ }^{+}-\mathrm{N}$ leaching past the roots zone tended to be lower by November of year 2. Significant differences due to $\mathrm{N}$ treatment were observed in the 4-year average leaf $\mathrm{N}$ concentration using repeated measures analysis; trees receiving soilapplied $3 \mathrm{x} \mathrm{N}$ in April had the highest leaf $\mathrm{N}$ values and trees receiving soilapplied $0.8 \mathrm{x} \mathrm{N}$ in July plus August had the lowest, with all trees in all treatments having slightly greater leaf $\mathrm{N}$ concentrations than the industry recommended 2.2\% (Lovatt and Witney, 2001). It should be noted that annual total yield and yield of CVS fruit were only weakly positively related to leaf $\mathrm{N}$ concentrations; yield of small fruit was not related to leaf $\mathrm{N}$ concentration. The poor relationship between leaf $\mathrm{N}$ concentration and yield of the 'Hass' avocado in California is not a new finding; it is well documented that avocado leaf analyses are not sensitive enough to detect changes in tree $\mathrm{N}$ status or fertilization rates that cause changes in yield (Arpaia et al., 1996; Embleton and Jones, 1972; Embleton et al., 1968; Lovatt, 2001; Lovatt and Witney, 2001; Yates et al., 1993). In the current research, the poor relationship between leaf $\mathrm{N}$ concentration and yield parameters cannot be attributed to deficiencies or toxicities in other nutrients. Leaf concentrations of $\mathrm{P}, \mathrm{K}$, $\mathrm{Ca}, \mathrm{Mg}, \mathrm{S}, \mathrm{Fe}, \mathrm{Zn}, \mathrm{Mn}, \mathrm{B}$, and $\mathrm{Cu}$ were all within the ranges considered optimal for avocado in California; leaf $\mathrm{Cl}$ and $\mathrm{Na}$ concentrations were below the values considered toxic (Jones and Embleton, 1978). Fertilization strategy influenced only leaf S, Mn, and Fe concentrations in years 1 and 2 and the resulting differences were not related to total yield or fruit size (Jones and Embleton, 1978). In addition, yield and $A B I$ were unaffected by climate conditions (maximum or minimum temperature or rainfall) during the four crop years of the research.

In light of the findings of this research, although intriguing, caution must be exercised in attempting to sustain total yield and yield of CVS fruit with only $40 \mathrm{lb} /$ acre $\mathrm{N}$ applied in July plus August for multiple years. Careful monitoring of tree $\mathrm{N}$ status would be required. However, in a situation of high leaf $\mathrm{N}$ concentrations, high soil $\mathrm{N}$ concentrations or significant amounts of $\mathrm{N}$ in the irrigation water where it is desirable to reduce avocado tree $\mathrm{N}$ status, reducing the annual total amount of soil $\mathrm{N}$ and applying it during the summer (July and August) to mitigate June drop and support exponential fruit growth, summer vegetative shoot growth and next spring's bloom would be a logical approach to solve this problem. This strategy would be cost-effective and contribute to greater net income to the grower, as well as offer increased protection of the environment by reducing the potential amount of $\mathrm{N}$ that could occur in the runoff water or pollute the groundwater. Compared with five soil applications of $\mathrm{lx} \mathrm{N}$, which produced equivalent 4-year cumulative and average total yields and yields of CVS fruit, $0.8 \mathrm{x} \mathrm{N}$ in July plus August would reduce a grower's fertilizer cost by $68 \%$ each year for as many years as it could be used without reducing tree $\mathrm{N}$ status below optimal. In addition, the reduced manpower required for two applications compared with five fertilizer applications per year, regardless of application method, would further reduce the cost of fertilizing an avocado orchard. Moreover, since all fertilizer rates were based on the amount of $\mathrm{N}$ provided, it is likely that other fertilizer sources of $\mathrm{N}$ would be equally effective as $\mathrm{NH}_{4} \mathrm{NO}_{3}$. In situations of low to optimal leaf $\mathrm{N}$ concentrations and the need to supply $\mathrm{N}$ fertilize to sustain tree $\mathrm{N}$ status due to low residual soil $\mathrm{N}$, applications of $\mathrm{lx} \mathrm{N}$ at the five key stages of tree phenology identified herein are justified. However, it is suggested that the January application be eliminated in cold wet winters, because $\mathrm{N}$ uptake would be compromised and the potential $\mathrm{N}$ leaching past the root zone would be increased. The rate of $\mathrm{Ix} \mathrm{N}$ should reflect the total annual $\mathrm{N}$ required to support the crop load on the trees, taking into consideration that in some growing areas both young and mature fruit might be on the tree simultaneously. Using only the amount of $\mathrm{N}$ fertilizer necessary to meet tree demand will help keep $\mathrm{N}$ fertilizer cost and the potential for $\mathrm{NO}_{3}{ }^{-} \mathrm{N}$ pollution of groundwater at a minimum. In developing a BMP for $\mathrm{N}$ fertilization of the 'Hass' avocado, the results presented herein should prove useful for adjusting the time of $\mathrm{N}$ application to match key stages of avocado tree phenology with high demands for $\mathrm{N}$ to increase total yield and yield of CVS fruit and to reduce the potential for $\mathrm{NO}_{3}{ }^{-} \mathrm{N}$ to leach into the groundwater.

\section{Literature cited}

Adato, I. 1990. Effects of paclobutrazol on avocado (Persea americana Mill.) cv. 'Fuerte'. Sci. Hort. 45:105-115.

Alva, A.K., S. Paramasivam, T.A. Obreza, and A.W. Schumann. 2006. Nitrogen best management practice for citrus trees I. Fruit yield, quality, and leaf nutritional status. Sci. Hort. 107:233-244.

Arpaia, M.L., J.L. Meyer, G.W. Witney, G.S. Bender, D.S. Stottlemyer, and P.R. Robinson. 1996. The Cashin Creek nitrogen 
fertilization trial-What did we learn? California Avocado Soc. Yrbk. 80:85-98.

Atucha, A., I.A. Merwin, M.G. Brown, F. Gardiazabal, F. Mena, C. Adriazola, and J. Lehmann. 2013. Soil erosion, runoff and nutrient losses in an avocado (Persea americana Mill.) hillside orchard under different groundcover management systems. Plant Soil 368(1-2):393-406.

Batjes, N.H. 2014. Total carbon and nitrogen in the soils of the world. Eur. J. Soil Sci. 65(1):10-21.

Bekey, R. 1989. Avocado timetable. California Grower 13(1):28-30.

California Department of Water Resources. 2009. CIMIS station reports. 25 May 2016. <http://www.cimis.water.ca. gov/cimis/data.jsp $>$.

Dixon, J. 2013. Better growing: Growing and presenting to the consumers the best quality Hass avocados. From the Grove 3(1):24-29.

Embleton, T.W. and W.W. Jones. 1972. Development of nitrogen fertilizer programs for California avocados. California Avocado Soc. Yrbk. 56:90-96.

Embleton, T.W., W.W. Jones, M.J. Garber, and S.B. Boswell. 1968. Nitrogen fertilization of the Hass avocado. California Avocado Soc. Yrbk. 52:131-134.

Embleton, T.W., W.W. Jones, C.K. Labanauskas, and W.J. Reuther. 1973. Leaf analysis as a diagnostic tool and guide to fertilization, p. 183-211. In: W.J. Reuther (ed.). The citrus industry. Univ. California Div. Agr. Sci., Berkeley.

Garner, L.C. and C.J. Lovatt. 2008. The relationship between flower and fruit abscission and alternate bearing of 'Hass' avocado. J. Amer. Soc. Hort. Sci. 133:3-10.

Garner, L., G. Klein, Y. Zheng, T. Khuong, and C.J. Lovatt. 2011. Response of evergreen perennial tree crops to gibberellic acid is crop load-dependent: II. $\mathrm{GA}_{3}$ increases yield and fruit size of 'Hass' avocado only in the on-crop year of an alternate bearing orchard. Sci. Hort. 130:753-761

Huett, D.O. 1996. Prospects for manipulating the vegetative-reproductive balance in horticultural crops through nitrogen nutrition: A review. Austral. J. Agr. Res. 47(1):47-66.

Jaganath, I. and C.J. Lovatt. 1995. Efficacy studies on pre-bloom canopy application of boron and/or urea to 'Hass' avocados in California. Proc. 3rd World Avocado Congr. 1:181-184.

Jones, W.W. and T.W. Embleton. 1978. Leaf analysis as a guide to avocado fertilization, p. 10. In: H.M. Reisenauer (ed.).
Soil and plant-tissue testing in California. Univ. California Div. Agr. Sci. Bul. 1879

Kalmar, D. and E. Lahav. 1976. Water requirements of the Avocado tree in the Western Galilee, Israel, 1968-1974. Agr. Res. Org. (Israel) Pamphlet No. 157.

Kiggundu, N., K.W. Migliaccio, B. Schaffer, Y. Li, and J.H. Crane. 2012 Water savings, nutrient leaching, and fruit yield in a young avocado orchard as affected by irrigation and nutrient management. Irr. Sci. 30(4):275-286.

Lovatt, C.J. 2001. Properly timed soilapplied nitrogen fertilizer increases yield and fruit size of 'Hass' avocado. J. Amer. Soc. Hort. Sci. 126:555-559.

Lovatt, C.J. 2011. Alternate bearing of 'Hass' avocado. California Avocado Soc. Yrbk. 93:125-140.

Lovatt, C.J. 2013. Properly riming foliarapplied fertilizers increases efficacy: A review and update on timing foliar nutrient applications to citrus and avocado. HortTechnology 23:536-541.

Lovatt, C.J. and G. Witney. 2001. Nitrogen fertilization of the 'Hass' avocado in California. AvoResearch 1(3):1-4.

Mangiafico, S.S., J. Newman, D.J. Merhaut, J. Gan, B. Faber, and L. Wu. 2009. Nutrients and pesticides in stormwater runoff and soil water in production nurseries and citrus and avocado groves in California. HortTechnology 19:360-367.

Meyer, G.A. and P.N. Keliher. 1992. An overview of analysis by inductively coupled plasma-atomic emission spectrometry, p. 473-516. In: A. Montaser and D.W. Golightly (eds.). Inductively coupled plasmas in analytical atomic spectrometry. VCH Publ., New York, NY.

Morales-Payan, J.P. and C.D. Candelas. 2013. Increasing organic avocado fruit yield using an Ascophyllum nodosum biostimulant and fertilization. Acta Hort. 1042:121-124

Nevin, J.M., T.W. Embleton, and C.J. Lovatt. 1990. Problems with urea-N foliar fertilization of avocado. Acta Hort. 275:535-541.

Pearce, S.C. and S. Dobersek-Urbanc. 1967. The measurements of irregularity in growth and cropping. J. Hort. Sci. 42(3):295-305.

Pella, E. 1990. Elemental organic analysis. Part 2. State of the art. Amer. Lab. 22(12): $28-32$

Rosecrance, R., B. Faber, and C.J. Lovatt. 2012. Patterns of nutrient accumulation in 'Hass' avocado fruit. Better Crops Plant Food 96(1):12-13.
Salazar-García, S., E.M. Lord, and C.J. Lovatt. 1998. Inflorescence and flower development of the 'Hass' avocado (Persea americana Mill.) during "on" and "off” crop years. J. Amer. Soc. Hort. Sci. 123:537-544.

Sotelo-Nava, H., O.G. Villegas-Torres, F. Perdomo-Roldán, E.H. Castro, A.D. Nava, and M.R. García. 2013a. Nutrimental diagnosis of avocado (Persea americana Mill.) 'Hass', soil fertility and water quality in Cuernavaca, Morelos, Mexico. Agr. Sci. 4(9):491-498.

Sotelo-Nava, H., O.G. Villegas-Torres, M.L. Domínguez-Patiño, E.H. Castro, A.D. Nava, A. Rodríguez-Martínez, and I. Alia-Tejacal. 2013b. Avocado nutritional diagnosis (Persea americana Mill.) "Hass", soil fertility and water quality in Ocuituco, Morelos. J. Chem. Chem. Eng. 7(11):1068-1073.

Sukamto, L.A., R. Lestari, and W.U. Putri. 2014. The effect of bio-fertilizers on plant growth and growth rate of grafted avocado (Persea americana Mill.). Intl. J. Adv. Sci. Eng. Info. Technol. 4(4):1-10

Switala, K. 1999. Determination of ammonia by flow injection analysis. QuikChem Method 10-107-06-1-A. Lachat Instruments. Milwaukee, WI.

U.S. Department of Agriculture. 2013. Web soil survey. 25 May 2016. <http:// websoilsurvey.sc.egov.usda.gov/App/ HomePage.htm>.

Wang, M., Y. Zheng, T. Khuong, and C.J. Lovatt. 2016. Developmental differences in antioxidant compounds and systems in normal and small-phenotype fruit of 'Hass' avocado (Persea americana Mill.). Sci. Hort. 206:15-23.

Wendt, K. 1999. Determination of nitrate/ nitrite by flow injection analysis (low flow method). QuickChem Method 10-10704-1-A. Lachat Instruments, Milwaukee, WI.

Whiley, A.W., T.S. Rasmussen, J.B. Saranah, and B.N. Wolstenholme. 1996. Delayed harvest effects on yield, fruit size and starch cycling in avocado (Persea americana Mill.) in subtropical environments. II. The late-maturing $\mathrm{cv}$. Hass. Scientia Hort. 66:35-49.

Yates, M.V., M.L. Arpaia, and B. Faber. 1993. Minimizing fertilizer contamination of ground water by fertilizer and irrigation management of avocados, p. 35-42. California Avocado Res. Symp., Riverside, CA.

Zilkah, S., I. Klein, S. Feigenbaum, and S.A. Weinbaum. 1987. Translocation of foliar-applied urea ${ }^{15} \mathrm{~N}$ to reproductive and vegetative sinks of avocado and its effect on initial fruit set. J. Amer. Soc. Hort. Sci. 112:1061-1065. 